\title{
建築家マックス・ヒンデルの経歴と作品について A BIOGRAPHY OF MAX HINDER, ARCHITECT, AND HIS WORKS
}

\author{
角幸博* \\ Yukihiro KADO
}

\begin{abstract}
Max Hinder(1887-1963), a Swiss architect, was born in Zurich on 20 th of January, 1887. In 1924, after pursuing his career as an architect in Switzerland, Germany, Austria etc., he came to Japan. He resided in Sapporo for three and half years till 1927, where he worked on numerous houses including his own, two mountain huts, two missionary schools-the Fuji (1924) and the Hokusei(1929), the St. Franciscan monastery(1925), a cathedral in Ni igata(1927) and other buildings, besides proposed a project for the architectural competition for the erection of a LEAGUE OF NATIONS BUILDING AT GENEVA in 1926. He moved to Yokohama in 1927 and continued his work untill the year of 1940, when he went to Germany. During these thirteen years, he designed the Jochi University(1931) and the St. Mary Hospital(1931) at Tokyo, a cathedral in Utsunomiya(1932) and others. He closed his earthly pilgrimage in Regen, a small town of Germany, in 1963.
\end{abstract}

\footnotetext{
Keywords: Max Hinder, architect, modern architecture, Switzerland, Hokkaido, Yokohama

マックス・ヒンテル、建築家、近代建築、スイス、北海道、横浜
}

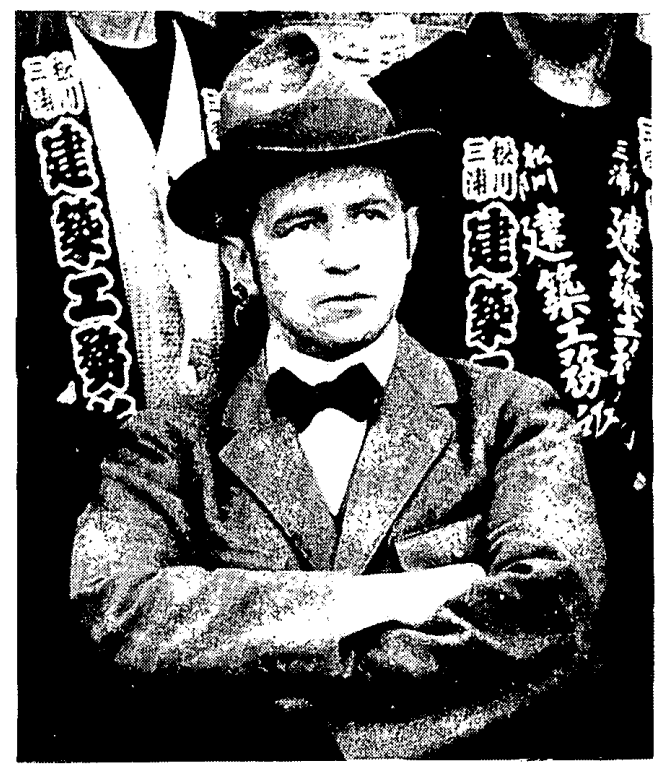

写真 1 来札当時(1924年)のM.ヒンテル(岡部洋子氏藏)

\section{1.はじめに}

マックス・ヒンデル Max Hinder(1887-1963)は、 大正末から昭和初期にかけて札幌市に滞在したスイス人 建築家である。1924年来道、3 年半の札幌市滞在後、横 浜市に移住し、1935年事務所解散まで在日外国人建築家 として活躍した。ヒンデルが札幌で活躍した頃の北海道 建築界は、北海道庁や主要都市、北海道帝国大学など、

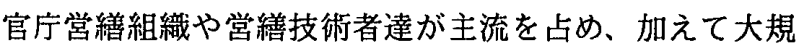
模な商業施設などに道外の建築家や建築事務所の作品が 見られたが、一方で田上義也 2 。など、組織に属さず、か つ職能に自覚的な自営建築家が来道し、北海道に根をお ろした時期でもあった。

本稿は、北海道における自営建築家の黎明期に活䠰し た建築家の一人であるヒンデルをとりあげ、その経歴と 作品活動について論じたものである。これまで経歴概要 ’や個々の作品については断片的に報告 ${ }^{4}$ しているが、 その後の調査により新たに知見を得た点があるので、あ 
らためて報告しておきたい。なお、来日以前の経歴や家 䒺については子息ハンス・ヒンデル Hans Hinder ${ }^{5}$ 氏 の教示により、また来日以降の作品活動については、ヒ ンデル直筆の襄書き付き写真(ハンス氏所蔵)を基本史料 に、関係者からの聞き取り、遺存設計図書、契約書によ る確認、カトリック新聞 記事調査などを根拠とした。

\section{2. 来日以前の経歴と家系}

ヒンデルは、1887年1月20日スイスのフルンテルンF1untern自治区のZürichbergstrasse 104で生まれた。フ ルンテルンは、1894年にチューリッヒ市の一部となった が、当時はチューリッヒ近瀿の自治区selbständige Nachbargemeindeであったという’。

父は、ルドルフRudolf Hinder(1864-1943)、母はエミ リー・シェーネンベルガーEmilie Schönennberger(1863 -1900)、3人兄姝の長男として誕生し、マックス・ルド ルフ・ヒンデル Max Rudolf Hinderと命名された。2人 の姝は、エミリーEmilieとルイーズ Louise(1891-1985) といった。ルイーズは、のち北海道大学予科ドイツ語教 授ハンス・コラー・ Hans Koller夫人となった人であり、 ヒンデルに札猊行を勧めた人である。

ヒンデル家は、15世紀以来、トゥールガウ Thurgau州 の小村ヴィレンWilenで代ヶ農業を営んでいたが、祖父 グレゴール・パンクランツ Gregor Pankranz Hinder II (1833-1878)の時代、1845年にチューリッヒへ移転し、 商人となった。父のルドルフは、教師務めの後、チュー リッヒ市の社会福祉局 Fursorgeamt上級公務員となった 人である”。

母方も、チューリッヒ湖に近いヘルリンベルグ Herrlibergという町で18世紀まで農家を営んできた家系であ った。ヒンデルは、こうした素性を恥じ、「父は、南ド
イツの貴族出身、母はフランス旧家の出身」との虚言す ら創作したという。もちろん一族からは、趣味の悪い几 談と、大いにひんしゅくをかったが、自分の出生を飾り たてようとするヒンデルの見栄張りな性格の一面を示す エピソードといえる7。

図 1 は、ハンス Hans Hinder(1909年生まれ) 氏が作成 したヒンデル家の家系で、17世紀までたどることができ る。

マックスは、1887年チューリッヒの小学校に入学、19 03年16歳で下級ギムナジウムUntergymnasium卒業後、チ ユーリッヒのBischef \& Wandele、チロンChilonのSchmidt \& Rossetのもとで、4 年間製図訓練Bauzeichnerlehreを受けた ${ }^{9}$ 。

当時、建築教育を特別受けずに建築家をめざす者は、 一般には最初の数年間Bauzeichnerlehreを修得し、その 後事務所を巡って技術を習得する過程をたどった ${ }^{\circ}$ 。著 名な建築家のもとには、多くの人間が集まり、競技設計 Wettbewerbe に参加するなどして腕を磨いたのである。 競技設計で成功した者は、建築家 “Architekt”として 独立したわけで、必ずしも建築教育を受ける必要はなか ったし、この名称にしても明確な基準があったわけでは なかった”。一方で “Diplom-Architekt”という称号が ある。大学で建築教育Archi tek turs tudi umを10-2semesters (学期) 終了し、卒業試験Diplom-Abschlußprüfungに 合格した者である1。。ヒンデルの場合は、前者の過程を 経て建築家として独立したわけである。

1907年から 14 年に兵役につくまでの 7 年間は、さらに ヨーロッパ各地の事務所を巡る修業時代であった。チュ ーリッヒを皮切りに、ロールシャッハRorschach、アー ラウAarau、クールChur、サン・モリッツ、ミュンヘン、 ベルリン、パリ、ブリュッセルなど各地を放浪し、多く の競技設計で成功したと伝えられる ${ }^{10}$ 。ドイツ工作連盟

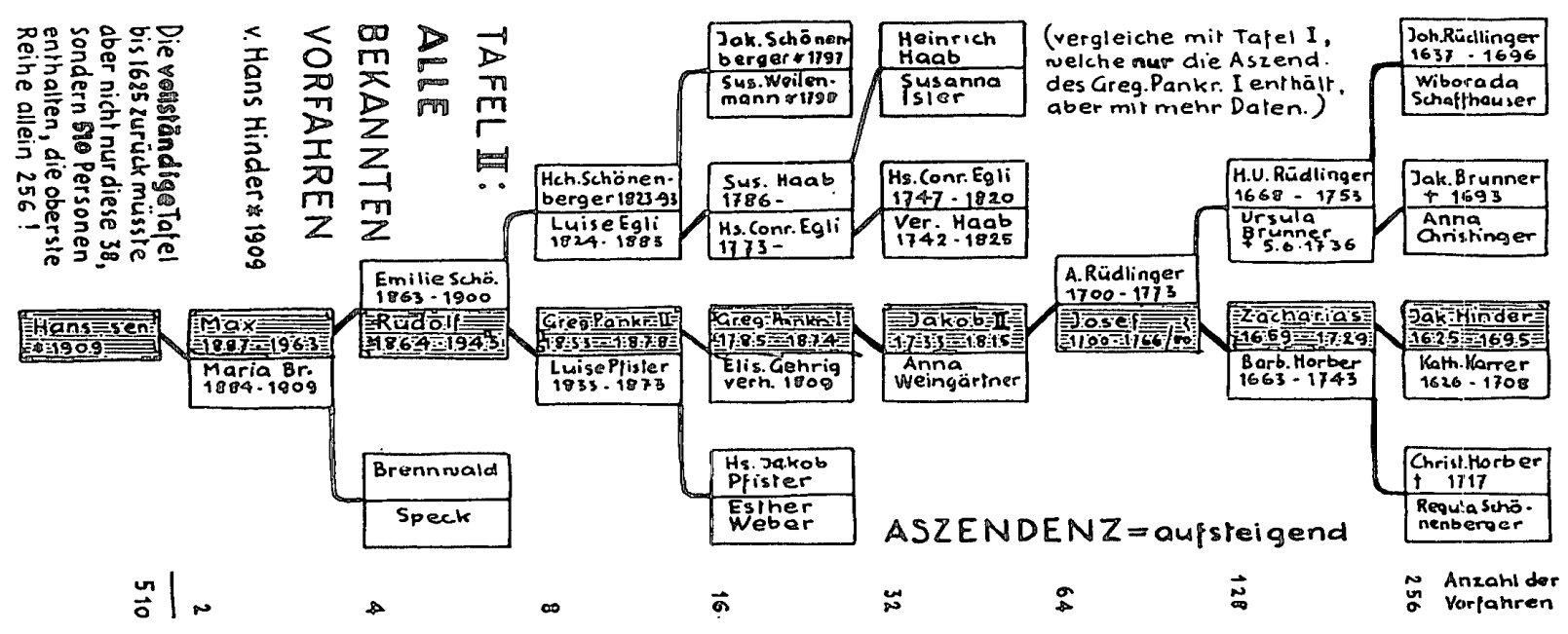

図 1 ヒンデル家家系図(ハンス・ヒンデル氏作成) 
の結成 (1907)やドイツの建築家 P . ベーレンスの活躍、 ベルリンで F . L .ライトの最初の作品集の出版(1910)な どがあった時代である。

この間1909年には、ハンスが誕生してまもなくマリア Maria Brennwald夫人(1884-1909)が他界している。

第 1 次世界大戦中、 2 年間スイス軍技術将校として兵 役後 ${ }^{1}$ 、1916年チューリッヒで設計事務所を開設。作品 としてはエブリAebli 邸などがあるという ${ }^{\circ}$ 。翌年ウィ ーンへ移って 4 年間過ごし、銀行などを手がけた ${ }^{2}$ 。19 21 年から 2 年間オーストリアのチロル地方に滞在し、ラ ンデックLandeck近郊のグリンGrinsに独立住宅を設計し たり、“Liceum Alpinum”のためのプロジェクトを発表 するなどしだ。

1924年 1 月義弟ハンス・コラー夫妻のすすめもあって、 北海道に永住 ${ }^{3}$ する決心で、アニーAnny夫人を伴いマル セイユから乗船した。日本へ到着したのは同年 3 月であ った。この船には、後に施主となる柳壮一夫妻も偶然同 乗していた ${ }^{4}$ という。

\section{3. 札幌時代 (1924-27)}

北海道永住の決意は、わずか 3 年半でくつがえされる ことになるが、札帽市での滞在期間中、柳壮一や、山崎 春雄、大野精七、アーノルド・グブラーArnold Gubler ら北海道大学教授連と交わり、彼らのパトロネージを受 けながら、精力的に設計活動を行なった。

札幌市内では、札幌藤高等女学校 (1924)、北星女学校 女教師館 (1926)、パラダイス・ヒュッテ（1926，1994年 倒壊)、ヘルヴェチア・ヒュッテ（1927)などの現存作品
をはじめ、札幌藤高等女学校笴宿舎 (1927)、北星女学校 寄宿舎 (1926)、聖フランシスコ修道院 (1925)、フランシ スコ会神学校 (1926)や住宅作品 (7 棟) などがある。函館 天使の聖母トラピスチヌ修道院 (1927)、新潟カトリック 教会 (1927)、日本基督教会札璂教会案 (1927)、上智大学 基本案（1927)などもこの期のものである。

来札当初、コラー家に身を寄せたが、その年札幌市北 11 条東 1 丁目に自部「東光園円い家」 ${ }^{15}$ (写真 2 ) と呼心゙ 16 角形平面の木造 2 階建て住宅を建設し、事務所を併設 した。札幌における設計活動の第 1 歩である。屋根頂部 に風見をつけ、こけら腲り外壁のこの住宅は、「北海道 建築にひとつのヒントを与えるもの」 ${ }^{16}$ として評価され 新聞にもとりあげられた ${ }^{18}$ 。ここでは、日本人所員楽間 利一郎、書生、女中を雇用していた。

同年札幌藤高等女学校 (写真 3) を設計、切妻大屋根を 強調する意匠や、裾広がりの急勾配屋根が特徴的で、破 風に小さな小屋裏採光用丸空をみせる。その後の作品に よく登場する意匠のひとつであった。主棟中央の小塔も ヒンデル好みのモティーフの一つで、北星女学校案 (192

8)や上智大学案(1927)などの基本設計でもみられた。

翌1925年「円い家」のすぐ北側に 2 番目の自期を建設 した。同年来札したグブラーに「円い家」を売却したた めであるが、ヒンデル自身満足できる作品ではなかった ${ }^{17}$ という。この年、柳邸(写真 4 )、大野期(写真 5 )、山 崎邸、林邸など、一連の木造住宅を設計した。イチイな どの丸太杭 9 尺程度のものを10数本も地面に打ち込むと いった慎重な構造的配虑、外壁をこけら張りや亜鉛鉄板 張りとする独特の防寒処理、引き戸や引き違い空といっ た和風建具の採用、通風換気の工夫としての床下開放、

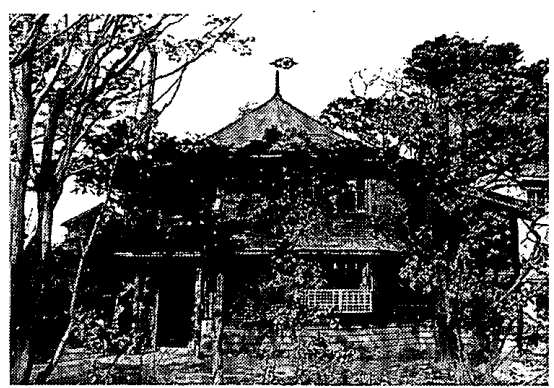

写真 2 東光園円い家(1924)

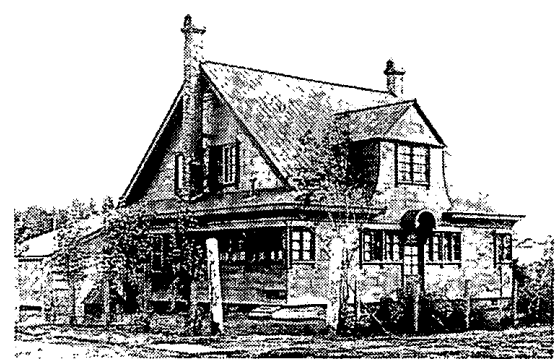

写真 5 大野精七的(1925)

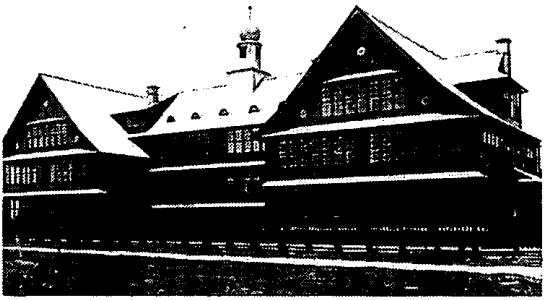

写真 3 札幙藤高等女学校(1924)

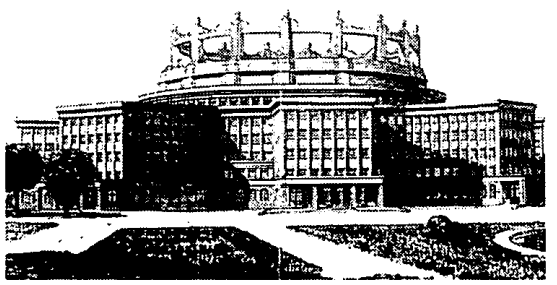

写真 6 ジュネーブ国際聯盟会館案(1926)

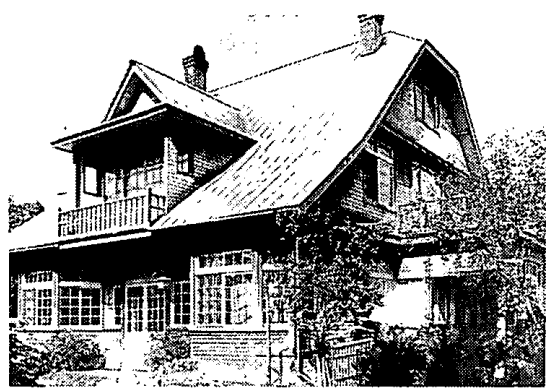

写真4 楖 壮一歌(1925)

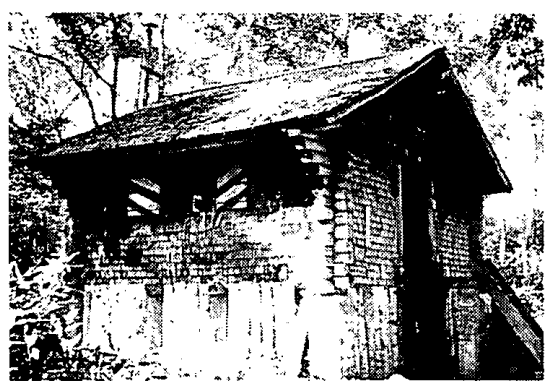

写真 7 ヘルヴェチアヒュッテ(1927) (山崎英雄氏蔵) 
フレアードルーフ（屋根勾配を軒近くで緩勾配とする裾 広がりの屋根) など、共通の特徴がみられる。

平面でも、居間・食堂・台所・ユーティリティの一連 なりの空間処理、南面するサロン・居間など団らんの場 の重視、主婦室や居間における主婦空間の確保、個室群 の確立など、近代住宅思想が展開されていた。

設計・管理に言葉の障害のあったことは想像に難くな いが、「札䚀の材料を思いがけぬことに使うので、その

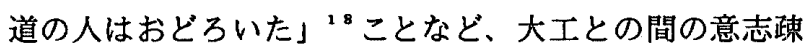
通にも苦労が伴ったことであろう。

気短かな性格であったというが、建築家としての使命 感と固い信念を持っていたことは、小論『新らしく家を 建てる人々へ』 ${ }^{19}$ からもうかがうことができる。建築家 の瞕能の未確立、同職能への一般の無理解といった当時 の状況をふまえると、「建築に関する計画及監督は建築 家に一任すべきである」と結論し、住宅を建てる際の施 主の心構えや、「建築家は、医師・裁判官・社会学者と 同一である」「医師と同様建築家を信頼せよ」「真の建 築家は又金銭さえ黃えば如何なる要求にも応ずる奴僕で はない」など、建築家の職能について一般読者への啓蒙 に努めたことは特筆すべきことであろう。

設計についても、自部円い家が『雪國に相応しい新し い建築』 ${ }^{18}$ として取材された際に語った記事によれば、 建築には樹木をとり入れることが建築の生命であること、 日本の伝統的な住宅は北海道の冬には適さないため、屋 根を簡単で急傾斜のものとし、日を南から入れるように するなど、北国の設計条件を入れた北海道向きの建築を つくるべきであることを唱えている。鬼門などの家相を 戒める一方で、当時の日本建築界における「コンクリー トの函が頻に建つ」 ${ }^{18}$ 傾向を「洵に心ない業です」 ${ }^{16}$ と憂 い、「何故日本建築のいい所をとり入れて日本独特の建 築を造らないか」 ${ }^{18}$ と「模做好きの日本人に対して」 ${ }^{18}$ 疑 問を投げかけている。

1926年には、北星女学校寄宿舎・同女教師館、パラダ イス・ヒュッテなどの作品がある。北星女学校の寄宿舎、 教師館は、1923年付けヴオーリズの基本案を受けての設 計であったが、教師館の平面こそ酷似しているものの、 外壁をからし色の鉄板張りとし、藤高等女学校やフラン シスコ修道院、大野邸などと類似のヒンデル風といえる 仕上げとしている。

パラダイス・ヒュッテは北大スキー部15周年事業とし て計画されたもので、ヒンデルも無儥で協力した。日本 初のスイス式山小屋ともいわれる ${ }^{20}$ グキャビンである。 のちのへルヴェチア(1927)、秩父宮殿下ヒュッテ(1928) と並ぶスキーヒュッテ 3 部作の第 1 号であり、その後の 札幌近郊のスキーヒュッテブームに大きな影響を与える ものであった。

この年にはまた、1926年 7 月25日を期して全世界の連
盟国の建築家に対して呼びかけられ、翌27年 1 月25日を 締切期限とするジュネーブ国際聯盟会館競技設計への応 募案(写真 6)も残されている。透視図と配置図写真が残 るのみであるが、透視図は総会会議場を描いたものと考 えられる。半円アーチ空をみせるルスチカ仕上げの下層 部と上部 4 層とで構成し、㓮りの梁い軒コーニスが頭部 を引き締める古典的な意匠で、主棵の中央頂部には手を つないだ人形周像を揭げている。

翌1927年、天使の聖母トラピスチヌ修道院（函館市湯 川，新潟カトリック教会、日本基督教会札幌教会案な どの宗教建築や札幌藤女学校寄宿舎、ノートン郎、ヘル ヴェチア・ヒュッテを中心に、上智大学の基本設計も始 まった。

日本基督教会札幌教会の設計は、北海道大学農学部林 学科教授新島善直を通じて依頼されたもので、同時に北 大水産専門部主事佐ヶ茂雄の紹介で、若い田上議也にも 依頼された。いわば 2 者による指名競技設計である。ヒ ンデル案は残されていないが、 $\mathrm{A}-1$ 版程の額 1 枚に透 梘図を描いたもので、木造 1 階建切妻屋根の簡単なもの であった ${ }^{21}$ 。設計費 2,000 円ということで教会側が難色 を示し、結局田上案が採用されることになる。

ヘルヴェチア・ヒュッテ(写真 7) は、ヒンデルとグブ ラーの共同出資により建てられた。ヘルヴェチアHelvetia は両者の命名で、スイスの古名、スイスを代表する 女神の名でもある ${ }^{22}$ 。 8 坪の小さなログキャビンで、外 壁を柾張り仕上げとした小屋であるが、札艄時代の最後 を飾る作品で、ヒンデル自らが「王宮を建てたよりも一 ヘルヴェチアヒュッテの建設が自分には深い喜悦であっ た」 ${ }^{22}$ と述べている。

\section{4. 楥浜時代 $(1927-40)$ 以降}

1927年10月、ヒンデルは、現在の横浜市中区本牧満坂 253 で設計事務所を開設した。この自邸兼事務所は、ド イツ人弁護士邸として現存し、当初のこけら張り外壁か ら下見板張りへの変更を受けているものの、木造 2 階建 ての既形はよく保たれており、居間部分への探光配虑、 ヒンデル好みの引違い建具の採用など、札幌時代の住宅 作品との共通点がみられる。

北海道永住の志を捨て、移転を決心した動機には、25 年 1 月29日のコラーの死去や、同年 3 月頃のコラー未亡 人スイス帰国などがあげられるが、より広い活動領域を 求めての転出とも考えられる。

新潟カトリック教会堂は、ヒンデルの横浜移転と同年 の1927年 9 月18日献堂式を挙げるが、竣工絵葉書の全景 写真の下には、「マックス ヒンデル 建築設計（横浜.札 㨪)」とあり、すでに横浜転出の準備が行われていたこと がうかがえる。 
横浜事務所では、札幌事務所開設以来のチーフ楽間利 一郎、札幌から転居した竹内一次のほか、鈴木熊作、川 喜田一雄らが勤めていた ${ }^{2}$ 。川喜田(1903.12.20-1988. $7.23)$ は、1921年県立神奈川工業学校卒業後、同年横浜 市技手補として勤務、1924年神奈川県朾警察部で建築申 請事務を扱っていた ${ }^{23}$ が、1929年 1月から所員として、 事務所解散(1935年)まで勤めた一人である。

この期には、札幌の北星女学校校含 (1929)、秩父宮殿 下ヒュッテ(現空沼小屋, 1928)、横浜の旭シルク(森住宅 (司令官ハウス,1927, 写真 8)、名古屋の熱田天主公教会 (1929)、恵方町天主公教会 (1931)、岐阜天主公教会 (192 9)、同幼稚園(1930)、金沢聖霊病院附属聖堂 (1931)など 木造建築のほか、東京の上智大学 (1931, 写真 9)、聖母 病院 (1931)、名古屋南山中学校本館 (1932, 写真10)、宇 都宮天主公教会 (1932, 写真11) などの R C 造の作品がみ られる。これら RC造の作品は、シャープなデザインを 意識しながらも、どことなく重く、部分的に装飾的な扱 いを見せるなど、ヒンデルの作風の一端を見る上で注目 される作品群ということができる。

この期の多くの作品活動では、新潟教会の設計を通じ て出会ったドイツ人ライネルスJoseph Reiners(1874-19 45）神父の存在を無視できない。ライネルスは、1912年 新潟教区長に就任、1922年から臨時名古屋教区長を兼任、 1926年名古屋区教区長に就任した人物であり、南山中学 校のほか、熱田、恵方町、岐阜、金沢の会堂建設の際に、 いずれもヒンデルを起用している。

ヒンデルの教会堂は、宇都宮天主公教会に代表される ように、双塔ないし単塔を擁したロマネスク風意匠のも のが多く、内部にも半円アーチの多用、感刻を施した方

円柱頭飾りの採用などがみられるが、宇都宮では大谷石 の採用、金沢聖霊病院附属聖堂では内部柱に黒漆塗りを 採用するなど、地域性を考虑した部分もみられる。クリ アストーリーに見られる円空は、ヒンデルが好んで採用 したもので、熱田、恵方町、岐阜、金沢などの会堂で共 通してみられるものであった。

設計活動のほか、ドイツ東洋文化研究協会 (OAG : Deutsche Gesellshaft für Natur und Völkerkunde Ostasiens)の委員会員としても活動し、OAG便り“Nachrichten der $0 \mathrm{AG}$ にもしばしば名前がみられたといゔ 。

1929年 1月の同協会における講演では、“Japanische Bausitten" (日本の建築風習 $)^{25}$ と題し、家相から地鎮 祭、地曳之式、釿初之式、上棟之式など建築に関わる風 習や祭事について言及しており、日本文化を深く理解し ようとしたヒンデルの一面をうかがうことができる。

1935年 5 月 31 日事務所を解散 ${ }^{2}$ し、翌36年 4 月 1 日に は0AG を脱会、第 2 次世界大戦のさしせまった1939年最 後のヘルヴェチア行のために来札(写真12)し、1940年戦 争まっただ中のドイツへと出発した。

ドイツ、バイエルン地方レーゲン Regenを最後の郷里 と決め、1 年間実業学校の教師を務めたこと以外、この 期についての詳細は不明である。1963年 1 月末、レーゲ ンで76歳の生涯を閉じ ${ }^{27}$ 、同地の共同墓地の一画に埋葬 された。ヒンデルにふさわしい素朴な木製十字架の墓標 には、「20.1.1887/M. R. HINDER/ARCHITEKT」 ${ }^{28}$ と記 されている。

\section{5. むすひ}

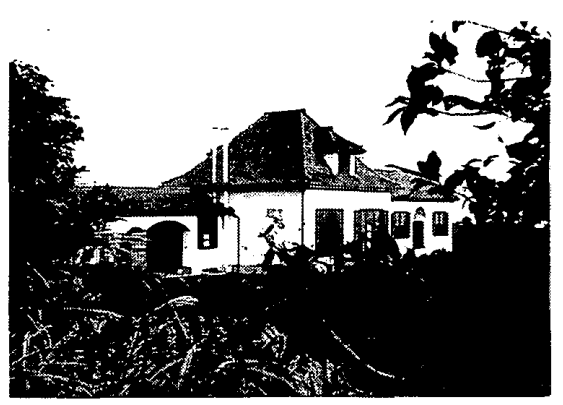

写真8 地シルク踭住宅(1928)

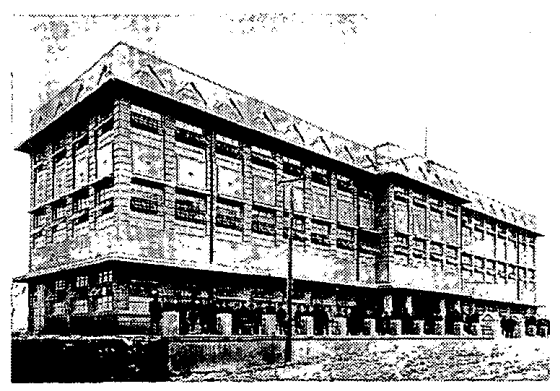

写真10 南山中学校本館(1932)(南山学園蔵)

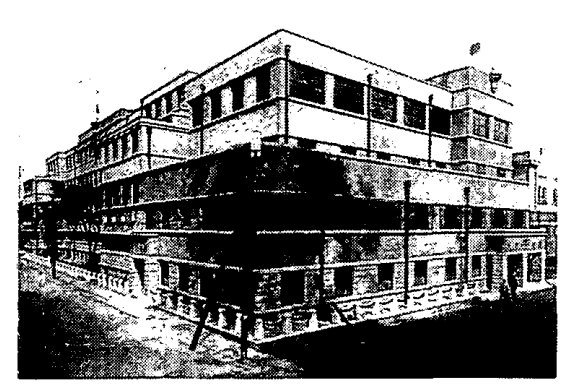

写真 9 上智大学(1932)

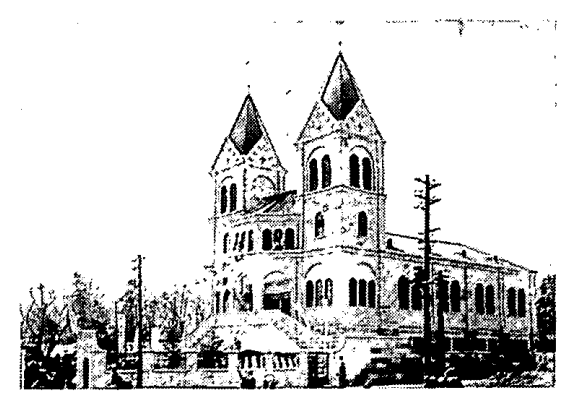

写真11 宇都宮天主公教会(1932)(吉田勝夫氏蔵)

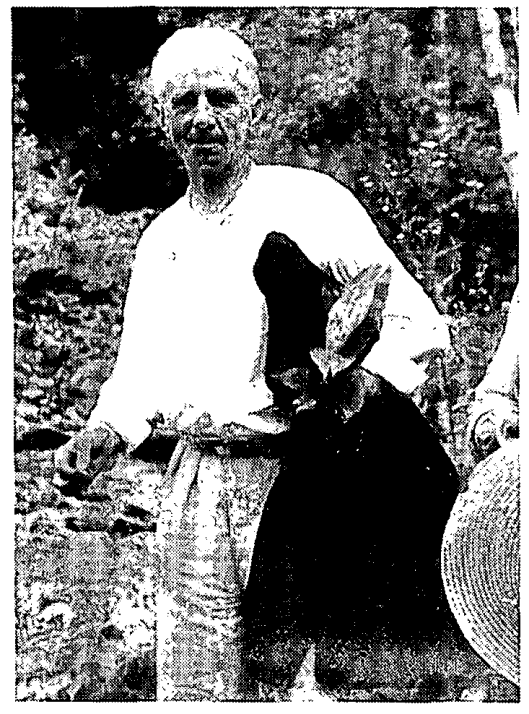

写真12 離日前(1939年)のヒンデル

（山崎泰雄氏蔵） 
表 1 M.ヒンデル年暊

\begin{tabular}{|c|c|c|c|c|}
\hline & & & 作 & \\
\hline 年 次 & 毛跲 & 徎 & 建筑 & カトリック系宗数庶晿 \\
\hline $\begin{array}{c}1887 \\
\text { 明治 } 20\end{array}$ & & 1.20 チューリッヒで藏生 & & \\
\hline $\begin{array}{l}1893 \\
\text { 明治 } 26\end{array}$ & $\dddot{6}$ & チューijッビの小学校入学 & & \\
\hline $\begin{array}{l}1903 \\
\text { 明治 } 36\end{array}$ & 16 & 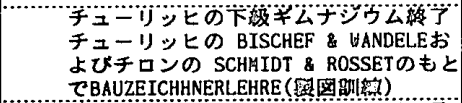 & & \\
\hline 1907 明治40 & 20 & 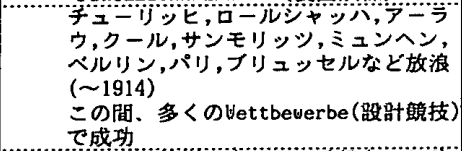 & & \\
\hline $\begin{array}{l}19140 \\
\text { 大正 } 3\end{array}$ & 27 & 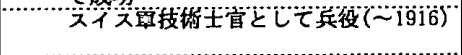 & & \\
\hline 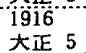 & 29 & 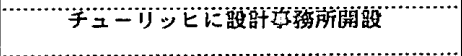 & AËBLITEB & \\
\hline 大正 6 & $30^{\circ}$ & ウイージに济在( & & \\
\hline 大正 10 & 34 & 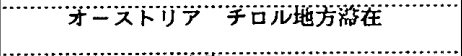 & クLiceud Alpinum のためのブロ & \\
\hline 大正13 & 37 & 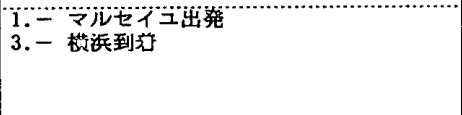 & 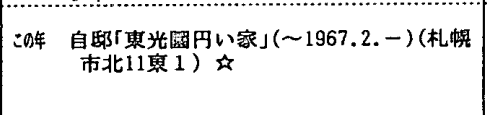 & 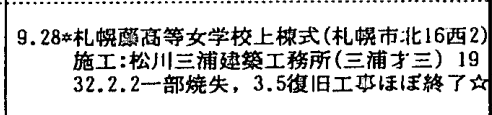 \\
\hline $\begin{array}{ll}1925 \\
\text { 大正14 }\end{array}$ & 38 & 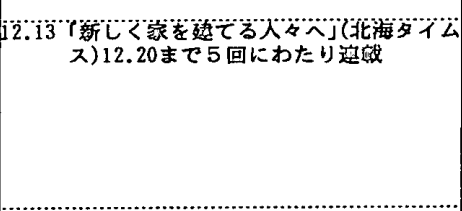 & 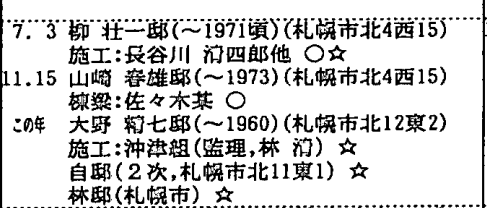 & 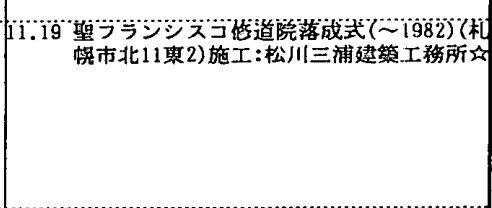 \\
\hline $\begin{array}{l}1926 \\
\text { 大正15 }\end{array}$ & 39 & & 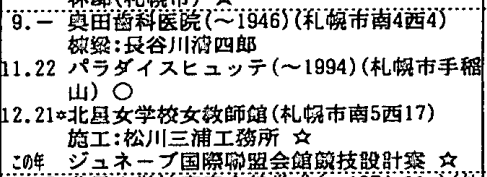 & 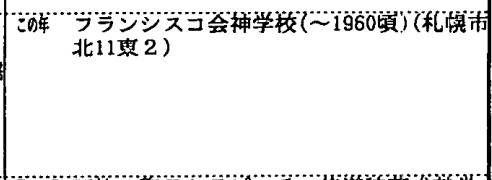 \\
\hline 昭和 2 & 40 & 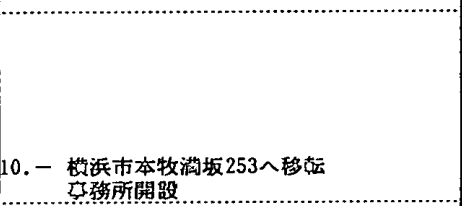 & 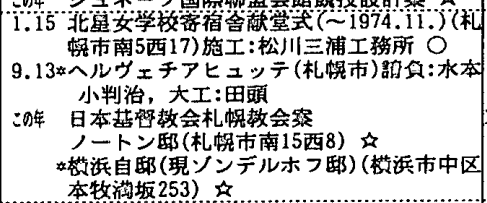 & 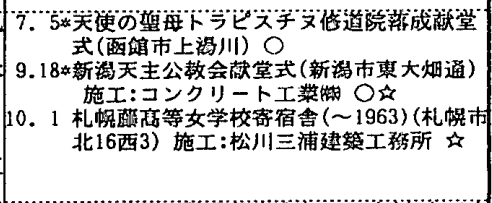 \\
\hline 1928 & $41{ }^{3}$ & & 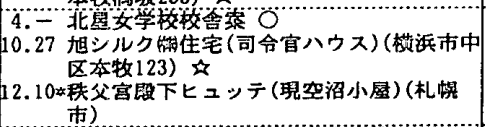 & 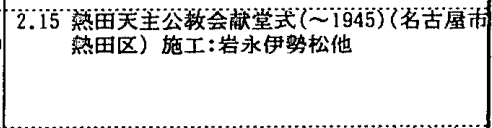 \\
\hline 昭和 4 & 42 & 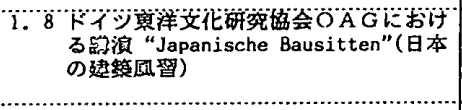 & 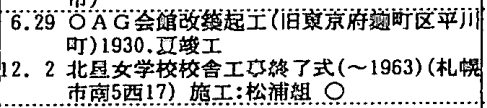 & 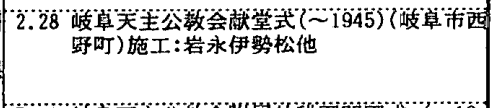 \\
\hline 1930 & 43 & & & 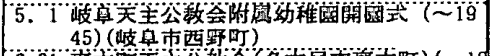 \\
\hline 昭和 6 & 44 & & & 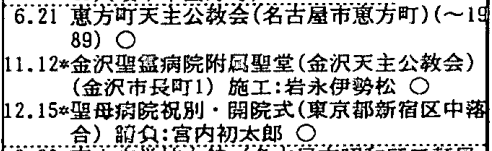 \\
\hline 昭和 7 & $45 \cdots$ & & & 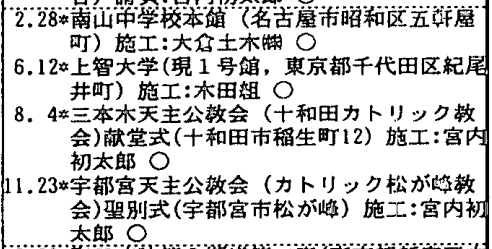 \\
\hline 昭和 9 & $\dddot{47}$ & & & 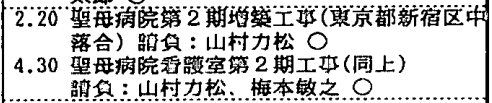 \\
\hline 昭和10 & 48 & 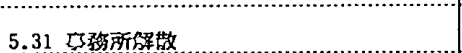 & & \\
\hline 1936 & 49 & 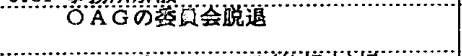 & & \\
\hline 昭和14 & 52 & 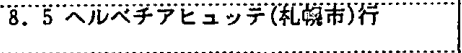 & & \\
\hline 1940 & 53 & 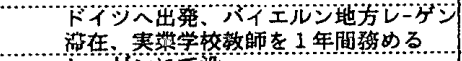 & & \\
\hline 的和38 & 76 & 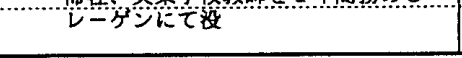 & & \\
\hline
\end{tabular}

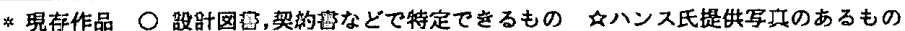


以上概説してきたマックス・ヒンデルの経歴と作品活 動を年譜としたのが、表 1である。表中、設計図書、契 約書などの史料で特定できるものについては○印で示し てある。

本稿では、滞在期間の短い札幌時代にやや重きを置い た。札幌では、北海道大学教授連との交流を通じてヒン デルの人物像がよく伝えられていること、スイスに似た 札幌の気候風土を意識した設計姿勢、建築家の職能に関 する新聞への投稿など、ヒンデルの建築観、意識をみて いく上で、重要と考えたからである。この期の作品とし ては、こけら㖘りや鉄板張りの防寒構造の木造住宅 (7) を中心に、ヒュッテ $3 、$ 学校(寄宿舎を含む) 4 、カトリ ック教会・修道院(神学校を含む) 4、医院 1 のほか、 日本基督教会札帽教会案やジュネーブ国際聯盟会館競技 設計案などを明らかにすることができた。

横浜時代には、1935年の事務所解散まで、住宅 $2 、 ヒ$ ユッテ 1、カトリック教会・付属施設 6 、会館 1 、病院 (增築工事も含める) 1 、学校 3 などの作品を残したが、 カトリック苏宗教施設の多い点が目を引く。特に、新潟、 岐卓、名古屋、金沢などのカトリック教会設計にあたっ ては、名古屋教区長を勤めたライネルス神父との交流が 大きく影響しており、その多くは、ロマネスク様式を意 識的に採用したものであった。さらに、南山中学校本館、 上智大学、聖母病院など RC造の作品群もヒンデルの作 風を見ていく上で注目されるが、本稿は、ヒンデルの作 品経歷を中心にまとめることに主眼を置いたため、個々 の作品分析やヒンデルの作風などについて、多くふれる ことができなかった。この点については、あらためて別 稿に譲ることとしておきたい。

\section{謝辞}

来日前の経歷および離日後の消息については、チュー リッヒ在の子息ハンス・ヒンデル氏との往復書簡によっ て多くを得ることができた。在日中の経歴については、 アーノルド・グブラー氏をはじめとするヒンデルの友人 知人の方名、個々の作品については関係者の方々に多大 な協力をいただいた。さらに、横浜開港資料館堀勇良博 士、名城大学理工学部畔柳武司氏には、資料提供や作品 調査などで多くのご教示をいただいた。また本稿作成に あたり玉木大樹、星野貴両君 (北海道大学大学院)に協力 いただいた。ここに記して、感謝の意を表します。

\section{注記}

1. Hinderはヒンダーと表記する方がー般的であるし、交遊関係のあった人 々も「ヒンダーさん」と呼んでいるが、1925年12月13日からの連載記事 の署名では「ヒンデル」とあり、また自身の事務所印やサインではすべ て「ヒンデル」と郡载しているので、本稿ではそれに従った。
2. 1899-1991。1918年 F.L.ライト設計の帝国ホテルの建設事務所に勤務 後、1923年の関東大霞災を契機に北海道へ渡る。戦前期の作品数約 160 件のうち半数以上が住宅である。製作勢にはライトの建等精神を生か しつつ、意識的にライト風から脱却し、独自の作風を見出す努力がぬら れる。拙稿『田上義也の初期作品について』(日本建築学会大会学術梗 概集，1985)、『大竹虎雄別邸(1922)について(田上義也研究 3)』（前同， 1991)など参照。

3. 拙稿『建築家マックス・ヒンデルについて』（日本建築学会大会学衍梗 概集，1978)、『建筑家マックス・ヒンデル MAX HINDERの経歷について』 (北海道大学工学部研究報告 第83号 1977)など。

4. 挰稿『建筑家マックス・ヒンデルMAX HINDER- 3 一名古屋南山中学校に ついて一』（日本建築学会北海道支部研究報告集 No.50，1979）、『建筑 家マックス ヒンデル MAX HINDER 3つのSki Hütteについて』（日本 建等学会大会学術梗概集, 1980)、『北星学園女教師館(大正15年)につい て』(同前,1981)、『宇都宮カトリック教会(1932)について』(同前, 19 82)ほか。

5. 1909-。マックス・ヒンデルの先妻マリア夫人との間に生まれた子息。 1928年から'30年にかけて、上智大学の設計・監理に從事したが、父マ ックスと過こしたたは在日の 1 年間だけであったという。

6. 1923年5月1日『カトリックタイムス』として創刊。1931年7月5日 『日本カトリック新聞』と改称。

7. ハンス・ヒンデル氏1988年 4月14日付け書简による。

8. 1881.10.4-1925.1.29。1908年より'25年まで、北海道帝國大学予科ド イツ語教師として在勤。

9. ハンス氏1976年3月13日付け書籍に、“Bauzeichnerlehre bei Schmid \& Rosset in Chilon und bei Bischof \& Weidele in Zürich "とあるが、 個人名会社名か不明。

10. ハンス氏1976年 3月13日付け書简による。

11. 山崎春雄「ヘルヴェチアヒュッテの建設 (承前)」(『山とスキー』第79 号 1928年)では、「世界大戦に墺国士官として従軍し負傷……とある がここでは前揭資料10によった。

12. 山崎春雄「ヘルヴェチアヒュッテの建設」(『山とスキー』第78号 1928 年)13. 北海タイムス1925年12月13日記事『新らしく家を建てる人々へ』 に、「北海道を永遠の住家と定めて」とある。

14. 机壮一の妻福子氏書简1976年 3月 5日付けによる。

15. 北星女学校奇宿舎設計図には「札幌市東光園円イ家建筑家ヒンデル」の印 がある。

16. 北海タイムス 1925年10月30日-31日記事『雪國に相磼しい新しい建筑』

17. ハンス氏提供の写真重に書かれていたヒンデル直筆の文による。

18. 柳时一の妻福子氏書简1976年 3月 5日付けによる。

19. 北海タイムス 1925年12月13日-20日。

20. 大野精七氏(1885.8.17-1978.9.5)敦。

21. 日本基督教会札㹸北一条教会役員、井口政治郎氏談。

22. 山崎春雄「ヘルヴェチアヒュッテの建設」(『山とスキー』第78号 1928 年)

23. 横活開港資料館堀勇良博士による1985年12月26日実施の川喜田一雄聞き 取りメモによる。

24. アーノルド・グブラー氏1976年 3月14日付け書简による。

25. 社団法人OA Gドイツ東洋文化研究協会会報 第22巻(1931)揭载。翻䛊 は、北海道大学文学部文学化独文学講座藤本純子助手の協力を得た。

26. ヒンデルが1935年 5月31日に事務所を解散するにあたり、1929年 1月31

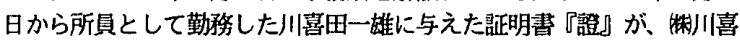
田建築設計事務所川害田敬忠氏のもとに保存されている。事移听解散後 の所員の再就職または独立を䁛念して記したものと考えられ、「事移所 解散ニ至ルマデ最後ノ一人トシテ勤務セリ」から始まり、事務所で携わ った仕事内容、上智大学建筑工事監督などに従事したことなどを挙げ、 「技能優秀二シテ着実部意ノ建筑家タル事习證シ大方ノ工事関保者諸氏 二推覀スルモノナリ」と結んでいる。ただ、この証明書のヒンデル建築 事務所の住所は、「東京都邀町区平河町式丁目七番地」とあり、事務所 解散時には横浜から東京に本拠を移していたと考えられるが、この点に ついては現在のところ確忍されていない。

27. ハンス氏1976年 3 月13日付け肃䉢による。

28.1984年9月現地調查による。

（1994 年 5 月 10 日原稿受理，1994 年 9 月 20 日採用決定） 